www.tijdschriftvoorwijsbegeerte.nl

Uitgave: Amsterdam University Press

\title{
Wat maakt blind? Liefde? Of Wetenschap?
}

Jan Bransen \& Giel Hutschemaekers

ANTW 107 (1): 95-116

DOI: 10.1557/ANTW2015.1.BRAN

\begin{abstract}
Blindness in therapy? Love? Or science?

In this paper we dispute what seems an obvious truism these days: that increasing the influence of scientific research on psychotherapy is a good thing. We begin with an exploration of two distinct capacities that contribute in significant ways to human flourishing: knowledge and love. We then argue that modern society rather onesidedly capitalizes on the growth of scientific knowledge. This has an important drawback because the dominant model of growth presupposed in scientific research is built on the idea of reducing the potentially disturbing influence of the subjective engagement of the scientist with the object of knowledge. This is ordinarily quite a fruitful idea that has, however, paradoxically bad effects in evidence-based therapy. This is the case, we argue, because in a scientifically informed therapy the therapist should, in some sense, try to be blind to the effects of his expertise on his clients' expectations of his expertise. A scientific, disengaged perspective therefore frustrates the therapist's need to invest in the formation of a charitable relationship with his clients. Next we argue that the popular prejudice against love - that it is blind - is not as plausible as it is considered to be. To be sure, love invites cognition to accept a subservient role, but, we argue, this has some advantages too. It encourages the lover to discern particularly positive and promising features of the object of his love, and this, we argue, is crucial to a successful therapy in two ways. On the one hand, the therapist needs to engage with these positive and promising features to succeed in building the needed charitable relationship with his clients. And on the other hand clients often go into therapy because they lack access to their own positive and promising features and are therefore unable to entertain a charitable relationship with themselves. We conclude that with respect to psychotherapy there might be good reason for contemporary
\end{abstract}


society to capitalize on the growth of love, rather than the growth of knowledge.

Keywords: love, psychotherapy, scientific knowledge, evidence-based, expertise, therapeutic relationship

Mensen gaan niet zomaar in therapie. Vaak heeft men zich langdurig afgevraagd of de klachten wel ernstig genoeg zijn, heeft men geprobeerd er zelf uit te komen en gaat men pas ten einde raad naar een therapeut - angstig, neerslachtig, schuldbewust en hulpeloos.

Waarin bestaat de meerwaarde van de therapeut? Heeft hij bijzondere kennis? Heeft hij bijzondere vaardigheden? Heeft hij een bijzondere positie? In reactie op deze vragen willen wij in dit artikel een drietal stellingen verdedigen: ten eerste, dat ons hedendaagse antwoord op bovenstaande vragen wel erg eenzijdig gedomineerd wordt door een eng wetenschappelijk (lees: positivistisch) perspectief; dat het, ten tweede, in therapie niet alleen om toepassen van wetenschappelijke kennis gaat maar vooral om menselijke betrokkenheid en interactieve vaardigheden; en dat, ten derde, onze samenleving er daarom goed aan zou doen om met het oog op onze geestelijke gezondheid stevig te investeren in de liefde.

De opbouw van dit artikel is als volgt. Eerst verkennen we vanuit een wijsgerig antropologisch perspectief de twee vermogens die traditioneel typisch menselijk zijn genoemd: kennis en liefde. Daarna laten we zien hoe de wetenschap deze twee vermogens uit elkaar heeft gespeeld, hoe daarbij kennis het primaat heeft gekregen en waarom dat voor therapie geen goede zaak is. We besluiten met een pleidooi voor het belang van liefde voor therapie.

\section{$1 \quad$ Een pratende diersoort}

Het is niet om het wezen van de mens te bepalen en daaruit onze conclusies te trekken, dat we beginnen vanuit een wijsgerig-antropologisch perspectief. Maar zo'n perspectief herinnert ons wel aan het feit dat we als mensen op de eerste plaats wezens zijn die in hun eigen biotoop proberen te overleven. Wij zijn ongebruikelijk lang op elkaar aangewezen, niet zo zeer als leden van een gemeenschap, of als partners, maar met name als ouders en als kinderen. Voordat het nageslacht op eigen kracht de uitdagingen van de natuurlijke omgeving te lijf kan gaan, zijn er vele jaren van zorg nodig, zorg waarin de ouders op elkaar moeten kunnen bouwen en de 
kinderen hun lichamelijke, sociale en cognitieve vaardigheden moeten zien te ontwikkelen.

Het zijn vooral de cognitieve vaardigheden die in onze Westerse traditie opgevallen zijn. Ons denken over onszelf wordt al sinds Aristoteles gedomineerd door de idee dat wij redelijke, denkende dieren zijn, een idee dat onder invloed van het Christendom vooral ging betekenen dat wij meer zijn dan ons lichaam, en dat de geest ons zo uniek maakt. Dat bijzondere belang van cognitie heeft zich moeiteloos een plaats verworven in de evolutietheorie van Darwin en diens erfgenamen. In dat verhaal is verrassend genoeg plaats voor een onderscheid dat ons in het werk van Plato nog de weg wees naar een transcendente werkelijkheid, het onderscheid tussen schijn en wezen. Voor Plato was het verschil tussen wat iets lijkt en wat iets is cruciaal. Zij die in staat zijn dat onderscheid te maken, verwerven kennis (epistèmè): toegang tot de abstracte, transcendente wereld van ideeën.

In het voetspoor van Aristoteles hebben evolutionair biologen er vervolgens een immanent onderscheid van gemaakt, dat begrepen kan worden als een alledaags natuurlijk gegeven. Als het in de evolutie om overleven gaat, om eten en niet gegeten worden, dan hebben organismen baat bij twee complementaire vaardigheden: camouflage en cognitie. Zorg er als prooidier voor dat je niet eetbaar lijkt en zorg er als roofdier voor dat je geen rover lijkt. Oftewel: benut de kansen die camouflage je bieden. Floreer bij de gratie van ambiguïteit: laat je tegenstanders denken dat je niet bent wat je wel bent. Tegelijkertijd moet je zelf leren de schijn van anderen wel te doorzien. Herken je prooi als je een roofdier bent en ontdek bijtijds de rover als je een prooidier bent. Oftewel: ontwikkel je cognitieve vaardigheden, doorzie de ambiguïteit die je omgeving je voorhoudt, weet wat werkelijk het geval is. ${ }^{1}$

Het is deze focus op kennis, waarheid en zekerheid die de Westerse cultuur sinds de oude Grieken gedomineerd heeft en die ten grondslag heeft gelegen aan de ontwikkeling van de moderne wetenschap. Die wetenschap is een sociaal arrangement waarin de intellectueel meest getalenteerde mensen vrijgesteld zijn om op systematische wijze een zo objectief mogelijk perspectief te ontwikkelen. Zo'n perspectief zou ieder individu de beste kans geven op het doorzien van de schijn van de eigen subjectiviteit en inzicht geven in wat werkelijk het geval is. De enorme technologische vooruitgang om onze omgeving naar eigen hand te zetten heeft deze focus zijn gelijk gegeven.

De betrekkelijkheid van deze focus gaat echter heel ver terug, en zit al vervat in de traditioneel dominante maar onfortuinlijk eenzijdige interpretatie van het zoon logikon als het 'denkend dier', daar waar het voor de 
Grieken evenzeer ging om een 'pratend dier', een met rede begiftigd dier, een dier dat redenen kan geven en om redenen kan vragen. Denken zou misschien nog een solitaire activiteit kunnen zijn, althans vanuit één enkel perspectief kunnen plaatsvinden - gezeten, weliswaar, op de schouders van onze grote voorgangers, maar kijkend in dezelfde richting als zij, voortbouwend op hun inzichten, gestaag doorwerkend aan die ene utopische, samenhangende, omvattende Theorie van Alles. Maar praten is in essentie een activiteit tussen mensen. Praten veronderstelt interactie en is een kwestie van spreken én luisteren. Praten impliceert gesprekspartners die op elkaar betrokken zijn. Praten vereist sociale vaardigheden. Dergelijke vaardigheden hebben met verbinding te maken, met kwetsbaarheid (omdat je in een gesprek jouw lot altijd ook in de handen van een ander legt) en met gastvrijheid (omdat je in een gesprek altijd ook de verantwoordelijkheid krijgt voor het lot van de ander), met taalvaardigheid en daardoor vooral ook met sensitiviteit en empathie. Met medemenselijkheid, compassie, en dus - hier is dat woord dat zijn schaduw al lang vooruit wierp - met liefde.

De Grieken gebruikten minstens drie verschillende woorden (eros, philia, agapè) voor dat vermogen van ons om verbinding te maken, om gepassioneerd te geven om anderen. Alle drie passen ze ook in een naturalistisch, evolutionair biologisch verhaal. Eros, vooral een kwestie van fysieke aantrekkingskracht, krijgt dan als voortplantingsmotor vanzelfsprekend een opvallende plaats. Maar voor een diersoort die gekenmerkt wordt door een lange tijd van kinderlijke afhankelijkheid is ook philia van groot belang, de vriendschappelijke affectie, de aanhankelijkheid en geborgenheid die maakt dat we elkaars aanwezigheid zoeken en genieten van de intimiteit en de sympathie die dat met zich meebrengt. Kinderen hebben die vanzelfsprekende aanwezigheid van hun ouders nodig. En dat impliceert dat er ook in het biologische verhaal over de mens ruimte is voor agapè, de onvoorwaardelijke en onbaatzuchtige inspanning voor het welzijn van een ander. ${ }^{2}$ Want het zijn de ouders die op elkaar moeten kunnen bouwen in die lange periode dat zij samen verantwoordelijk zijn voor een nageslacht dat nog alsmaar niet voor zichzelf kan zorgen. Ouders moeten in staat zijn tot onbaatzuchtige en onvoorwaardelijke overgave. Zij moeten trouw kunnen zijn, in voor- en tegenspoed, en tot de dood hen scheidt. Voor een pratende diersoort wordt het daadwerkelijk mogelijk elkaar die trouw te beloven, waardoor elkaar de liefde verklaren een daad wordt die het actuele moment van concrete interactie overstijgt, een daad die een tijdloze verbondenheid realiseert voorbij de beperkte kaders van de vergankelijkheid. 
Wij willen niet suggereren dat de eerste mensen ook op de savanne al hun zuivere liefde bezongen. Maar een pratende diersoort onderhoudt niet alleen zakelijke contacten. Onze taal is ook de taal van de poëzie, van de liefde die banden smeedt over onze tekortkomingen en dierbare kwetsbaarheden heen. Die banden hebben onze kinderen nodig, in hun vertederende afhankelijkheid van zorg en aandacht. Maar ook partners en ouders hebben die liefdesband nodig omdat zij het alleen niet redden. Mensen zijn op elkaar aangewezen en liefde maakt dat gemakkelijk. Dat was al zo op de savanne, en dat is nu nog steeds zo, in dorpen, stadsjungles en vinexwijken. En ook in zorgcentra, gemeentehuizen en universiteiten.

\section{$2 \quad$ Een voorbeeld}

Laten we onze abstracte en verheven wijsgerig-antropologische bevindingen eens concreet vorm geven door haar toe te passen op een alledaags voorbeeld.

Het gaat niet goed met Anne, de zeventienjarige dochter van Henk, een anesthesist, en Ingrid, die Nederlands doceert. Sinds enige tijd bezoekt Anne veel te vaak feesten waar ze geniet van joints en pilletjes en flink veel alcohol drinkt. Inmiddels is Anne tot twee keer toe comatisch afgevoerd naar het ziekenhuis. Maar Anne wijst alle bezorgde vragen af en vindt zichzelf helemaal niet onverantwoord bezig. Aan tafel ontstaat een strijd. Ingrid vindt dat er gepraat moet worden, maar Anne wil dat niet. Ze vindt haar moeder een tuttige bemoeial. Anne weet echt zelf wel wat zij doet en wat goed voor haar is. Langzaam maar zeker begint de zaak uit de hand te lopen, worden deuren steeds vaker dichtgesmeten, weigert Anne nog aan tafel te komen en valt ze ook nog eens flink af. Henk komt uiteindelijk tussen beide en dwingt zijn dochter in te stemmen met een zoektocht naar passende zorg. Hij zal het voortouw nemen. Hij kent immers de weg in de gezondheidszorg en consulteert collega's.

Wat is er aan de orde in die zoektocht naar passende zorg? Het hedendaagse antwoord op die vraag lijkt simpel en eenduidig. Het ontbreekt Anne, Henk en Ingrid aan voldoende kennis. Henk maakt zich zorgen over zijn onvermogen schijn van wezen te onderscheiden. Hij weet niet wat hij van de ambiguïteit van de situatie moet denken, en vreest dat hij zich laat misleiden door de schijn van wat zich voordoet. Zijn cognitieve vaardigheden schieten te kort en dus moet er raad gezocht worden bij deskundigen, zij die in staat zijn een correcte diagnose te stellen van wat er met Anne aan de hand is. Hij vertrouwt Annes inzicht in het onder- 
scheid tussen schijn en wezen niet, evenmin als dat van Ingrid, zijn vrouw. Anne zit er naast. Dat is evident. Zij blowt en drinkt te veel en kan duidelijk haar grenzen niet bepalen. In Henks ogen schiet ook Ingrids inzicht te kort Zij probeert haar invloed te laten gelden, macht uit te oefenen, maar tevergeefs; Anne is zeventien. Zij laat zich niet meer dwingen. Blijkbaar is Ingrid niet in staat schijn en wezen van haar eigen onmacht te doorzien, noch schijn en wezen van Annes problemen.

In de zoektocht naar passende zorg is er ogenschijnlijk geen sprake van een behoefte aan meer en betere liefde. Misschien wel aan het tegendeel. Henk en Ingrid houden misschien wel te veel van Anne. Zij maken zich zorgen omdat ze haar niet meer kunnen bereiken. Annes perspectief is hen vreemd, even vreemd als het voor Anne zelf moet zijn. Daarom zoeken zij de hulp van een deskundige, iemand die de juiste diagnose kan stellen, iemand die de schijn kan doorzien, iemand die achter de symptomen het mechanisme ontdekt dat verantwoordelijk is voor Annes verslaving, een mechanisme dat, juist vanwege hun subjectieve betrokkenheid, verborgen blijft voor Anne, Ingrid en Henk. Het ontbreekt hen aan kennis en inzicht. Dat staat voor Henk buiten kijf. Pathologieën zijn gecompliceerde zaken; de kans is groot dat Anne steeds verder zal afglijden. Dat is gevaarlijk.

\section{Wetenschappelijk verantwoord interveniëren}

Onze samenleving verwetenschappelijkt in hoog tempo. Er is vrijwel geen levensdomein meer te vinden dat niet ingrijpend is getransformeerd door wetenschappelijke kennis. De standaardreactie op verwetenschappelijking is positief. Of het nu om sportschoenen, internetbankieren, of duurzame katoenproductie gaat: het lijkt altijd onomstotelijk beter voor een domein als de wetenschap zich er mee bemoeit. Dat geldt ook voor de geestelijke gezondheidszorg. Gezondheid is van oudsher een goed geweest dat de aandacht van de wetenschap heeft getrokken en gekregen. De enorme vooruitgang in de lengte en de kwaliteit van ons hedendaagse leven is rechtstreeks te danken aan de grote ontdekkingen van de moderne wetenschap. Waarom zou dat niet gelden voor de geestelijke gezondheid? Ook hier is het lichaam-geest dualisme achterhaald. Het heeft niet alleen voor filosofische en praktische moeilijkheden gezorgd, het heeft ons ook gehinderd in de wetenschappelijke bestudering van onze eigen psyche. Gelukkig is dat veranderd. De wetenschappelijke psychologie boekt grote successen. Er is natuurlijk nog wel een lange weg te gaan omdat ons brein zo buitengewoon complex is. Bovendien is ons alledaagse zelfbegrip - individueel 
en collectief - een meester in misleiding. Hulde daarom aan de psychologische wetenschap die de misleidende wensdroom van onze verstandige, autonome redelijkheid ontmaskert. ${ }^{3}$

Een van de parels op de kroon van de psychologie is de evidence-based cognitieve gedragstherapie (CGT). ${ }^{4}$ CGT is gebaseerd op de aanname dat menselijk gedrag in belangrijke mate beschreven kan worden in termen van stimulus-responsketens, en uiteindelijk verklaard kan worden met behulp van onderliggende mechanismen, die somatisch, emotief of cognitief van aard kunnen zijn. Alleen door meer inzicht in die mechanismen kunnen wij meer begrijpen van ons gedrag, en kunnen we disfunctioneel gedrag corrigeren. Dat vraagt om veel gedetailleerd, hoogwaardig en geavanceerd wetenschappelijk onderzoek. Een alternatief is er niet en hoewel het lang kan duren (gezien de enorme complexiteit van ons brein), lopen we met investeringen in de wetenschap niet echt een risico. Zeker, er zijn uitwassen van carrièrisme, commercialisme en dogmatisme, maar wetenschap is principieel democratisch en heeft een sterk zelfreinigend vermogen. De affaire-Stapel is misschien slecht voor het imago van de psychologie maar niet schadelijk voor de groei van de wetenschap. Daarvan getuigt immers de doortastende manier waarop de wetenschappelijke gemeenschap in reactie op de affaire-Stapel onmiddellijk haar rationaliteit heeft weten te bekrachtigen.

Terug naar Henk, Ingrid en Anne. Zij moeten op zoek naar een goede psycholoog die op de hoogte is van de laatste stand van wetenschap en veel ervaring heeft in de diagnostiek en behandeling van de problemen van Anne. Hoe meer deze voldoet aan dat ideaal van de scientist-practitioner des te groter de kans dat Anne weer spoedig zal herstellen. Garanties zijn niet te geven, maar bij hem zijn ze op de beste plaats. Hun hulpvraag komt immers voort uit een tekort aan kennis. Doordat zij te weinig inzicht hebben in de onderliggende mechanismen lukt het Henk en Ingrid en ook Anne zelf niet om adequaat om te gaan met Annes verslaving. Misschien is er wel sprake van een hersenziekte, en dan is een adequate diagnose prerogatief. Mocht de therapeut naast kundig ook nog aardig, lief en begripvol zijn dan is dat mooi meegenomen, Noodzakelijk is dat echter niet, aldus de hedendaagse consensus.

\section{Objectief, onbevooroordeeld, transparant. En blind}

Wetenschap is een collectieve prestatie van wereldformaat. Het is waartoe wij samen in staat zijn gebleken bij het optimaliseren van onze cognitieve 
vaardigheden, gericht op het steeds scherper onderscheiden van schijn en wezen. Schijn is wat iets lijkt doordat het vertekend wordt door ons subjectieve, vooringenomen en vertroebelende perspectief. Hoe minder dat perspectief zijn stempel drukt op wat zich in de ervaring aanbiedt, des te zuiverder ons zicht wordt op wat is, op de werkelijkheid zelf. Wetenschap is daarmee een dubbele zoektocht: enerzijds naar te elimineren verstoringen van ons perspectief en anderzijds naar een wereldbeeld dat in objectieve zin zo adequaat en accuraat mogelijk is. Wetenschap is intrinsiek kritisch. Wetenschap is niet alleen gericht op kennis, maar altijd ook gericht op het verantwoorden van die kennis, op het kunnen onderbouwen van de claim dat kennis inderdaad kennis is. Wetenschap gaat altijd ook over haar eigen methodologie. Wetenschap impliceert wetenschapsfilosofie, juist om te voorkomen dat zij gebouwd wordt op methodologische dogma's in plaats van op bereflecteerde vooronderstellingen.

In dit artikel bekritiseren wij één onbereflecteerde en vooral erg naïeve vooronderstelling: dat wetenschap hoort te streven naar een zo perspectiefloos mogelijk perspectief. De onderliggende idee lijkt te zijn dat in de limiet cognitie geen relatie of engagement met de omgeving is. Wie iets weet van de werkelijkheid, heeft het over die werkelijkheid zelf, zoals die op zichzelf beschouwd is. Die kennis staat los van de eigenaar van die kennis en dus los van hoe deze persoon op die werkelijkheid betrokken is en zelf in die kennis aanwezig is. Idealiter gaat die kennis alleen maar over de werkelijkheid. Kennis toont wat het geval is, omdat alle schijn eruit verwijderd is en alle subjectieve, partijdige en perspectivistische vertekeningen er uit geëlimineerd zijn. Precies dat is de pretentie en het succes van wetenschappelijke kennis. Wie die kennis verworven heeft en hoe die kennis verworven is, kan wetenschapshistorisch interessant zijn, maar staat los van die kennis zelf en zegt uiteindelijk helemaal niets over wat die kennis tot kennis maakt.

Wetenschapsfilosofen zetten al lang grote vraagtekens bij dit positivistische zelfbeeld van de wetenschap. ${ }^{5}$ Wij zullen die kritiek hier niet herhalen. Ons betoog beperkt zich tot de rol die wetenschappelijke kennis toebedeeld krijgt in de evidence-based cognitieve gedragstherapie. We realiseren ons dat als je cognitie smal opvat, en gericht bent op het elimineren van de schijn, dat het dan voor de hand ligt om te denken dat de eigen subjectieve en partijdige blik in potentie de grote boosdoener is. En dan ligt het dus ook voor de hand om te streven naar een vorm van contact met de werkelijkheid die transparant en zuiver instrumenteel is, een vorm van contact waarin het niet om het contact zelf gaat, niet om de relatie met die werkelijkheid, maar alleen om die werkelijkheid zelf. Het ideale resultaat is 
dan een objectieve en neutrale theorie. Dat we vervolgens in de toepassing van die theorie weer contactproblemen krijgen, om ze zo te noemen, is wetenschaps-intern gezien volkomen irrelevant. Zulke contactproblemen zijn praktisch van aard, zijn ingenieursproblemen die in de meer natuurwetenschappelijke domeinen met behulp van slimme technologie beheerst kunnen worden. Dat die beheersing in de sociale wetenschappen zoveel moeilijker is, hoeft voor de sciëntistisch positivistische ideologie geen bedreiging te vormen zolang maar duidelijk blijft dat kennisproductie één zaak is en kennistoepassing een heel andere.

Het is echter precies dat vooronderstelde onderscheid tussen kennisproductie en kennistoepassing dat in de wereld van het menselijk gedrag voor problemen zorgt en tot een interpretatie van therapie leidt die niet vol te houden is. De blindheid van wetenschap voor haar eigen perspectief wreekt zich zodra wetenschappelijke kennis een rol gaat spelen in sociale interactie. Laat ons dit toelichten.

In het domein van de psychopathologie is de therapeut, volgens de hierboven beschreven naïeve wetenschapslogica een soort technoloog of ingenieur, die als evidence-based practitioner de levensomstandigheden van mensen kan verbeteren omdat hij meer dan anderen beslissend door de wetenschap geïnformeerd is en dus kennis heeft van wat werkelijk het geval is. Omdat hij weet heeft van determinanten en consequenten (van onderliggende mechanismen) kan hij een inschatting maken van te beïnvloeden effectieve krachten. Gekoppeld aan zijn praktische vaardigheden beschikt hij over de expertise de levensomstandigheden zo te manipuleren dat zij gunstiger gaan uitpakken voor zijn patiënten. Aan de ene kant stelt zijn wetenschappelijke kennis hem in staat de juiste diagnose te stellen en de juiste behandeling voor te schrijven en aan de andere kant stelt zijn praktische ervaring hem in staat die behandeling correct en effectief toe te passen. Natuurlijk is dit een ideale voorstelling van zaken en is de kwaliteit van de wetenschappelijke modellen in het domein van de psychopathologie bij lange na nog niet vergelijkbaar met de modellen waarover natuurwetenschappelijk georiënteerde ingenieurs de beschikking hebben. Maar dat is een kwestie van tijd. Althans... dat denkt de gedragswetenschapper die blind is voor zijn eigen blindheid.

Want er is een cruciaal verschil! In de therapie is de therapeut zelf voor de cliënt namelijk de beslissende levensomstandigheid. Natuurlijk kan de therapeut zichzelf proberen uit het scenario te schrijven door over zichzelf te denken als de neutrale uitvoerder van interventies of als materialisatie van een onpersoonlijk protocol. Maar daarin wordt hij onmiddellijk ingehaald - en onderuitgehaald - door zijn cliënt, voor wie hij nooit enkel een 
schakel in het mechanisme is, maar een professional, een deskundige, een autoriteit, iemand die het weet, kortom de meest effectieve kracht in de therapeutische setting. De Amerikaanse psychotherapeut Jerome Frank (Frank en Frank 1993) gaat nog een stap verder door te betogen dat deze verwachtingen van veronderstelde deskundigheid in combinatie met de definitie van de bijeenkomst als een healing environment noodzakelijke voorwaarden zijn om psychotherapie effectief te maken.

Als Henk, Ingrid en Anne bij een therapeut terecht gekomen zijn, dan ontmoeten zij een mens, een bijzonder mens, iemand die meer weet over hen dan zij zelf. Juist die verwachting ten aanzien van zijn expertise maakt van de therapeut een effectieve kracht. In een therapie kan de strikt wetenschappelijk opererende therapeut proberen een volkomen objectief, onbevooroordeeld en transparant perspectief in te nemen en zo als het ware zelf in de therapie afwezig proberen te zijn. Maar de werkelijkheid die deze therapeut gewaar wordt bestaat uit cliënten die met hun omgeving interacteren, en dat wil zeggen, cliënten voor wie de therapeut helemaal niet afwezig is, maar voor wie hij juist de cruciale factor is in hun therapeutische levensomstandigheid. De sociale werkelijkheid die de gedragswetenschapper bestudeert is met andere woorden een relationeel verband waar de wetenschapper-therapeut zelf wezenlijk deel van uitmaakt. De wetenschapper kan zichzelf wel proberen buiten beeld te houden, alsof hij alleen maar een afstandelijke en onbetrokken toeschouwer is, maar als therapeut wordt hij altijd onmiddellijk door zijn eigen onderzoeksobject (door zijn cliënten) die te bestuderen werkelijkheid ingetrokken.

Dat maakt van sociale wetenschap een praktijk waarin observationele kennis niet kan zijn wat het pretendeert te zijn. Van natuurlijke objecten kan nog gezegd worden dat zij zelf geen contact zoeken met de kennis die er over hen in de wetenschap ontwikkeld wordt. Maar mensen zoeken dat contact wel, met de kennis die ze denken dat anderen over hen hebben evenzeer als met de wetenschappers die ze die kennis toedichten. Ook al doen de gedragswetenschappers nog zo hun best om zichzelf in hun laboratoria volstrekt onzichtbaar en inert te maken, alsof ze aan gene zijde zijn van de werkelijkheid die ze bestuderen, dat transcendente lot is de kennis die ze produceren zelf niet gegund. Die kennis komt altijd die werkelijkheid weer binnen, en niet eens als een per ongeluk werkzame kracht in een goed geïnformeerde scientist-practitioner, maar juist als zelf een object van aandacht voor de bestudeerde en te behandelen cliënten. Cliënten kunnen namelijk niet laten te doen wat gewone mensen nu eenmaal altijd doen: rekening houden met wat ze denken dat anderen over hen denken, een betrekking aangaan met die anderen maar ook met de kennis over henzelf 
die zij die anderen toeschrijven. In hun verwachtingen van anderen zijn mensen altijd betrokken op de verwachtingen die zij die anderen toeschrijven, zoals ethnomethodologen als Garfinkel en Goffman in het voetspoor van George Herbert Mead en Alfred Schütz uitgebreid bestudeerd hebben. ${ }^{6}$ Het is volgens ons van groot belang dat de wetenschappelijk geschoolde therapeut zich bewust is en blijft van deze natuurlijke neiging van mensen zich te betrekken op elkaars definitie van de situatie waarin zij zich bevinden. Daarmee zal de therapeut beseffen dat hij deel uitmaakt van een sociale realiteit die mede geconstitueerd wordt door de kennis, en de kennis van die kennis, die de betrokkenen bij elkaar vooronderstellen. ${ }^{7}$ Geen therapeut kan zich immers permitteren daarvoor blind te zijn.

\section{$5 \quad$ De liefhebbende blik}

Het spreekwoord wil dat liefde blind maakt. De kwestie is niet slechts dat de liefhebbende persoon het effect van zijn eigen perspectief op zijn representatie van de geliefde persoon negeert. De blindheid gaat veel verder. De liefhebbende persoon zet zijn eigen cognitieve vaardigheden namelijk principieel op de tweede plaats, ten dienste van een niet objectief gefundeerde extreem positieve evaluatie van de geliefde persoon. Liefde zet de geliefde persoon in het zonnetje en op een troon. Hij of zij is buitengewoon aantrekkelijk, verdient alle aandacht, en hem of haar te laten bloeien is wat het eigen leven de moeite waard, geslaagd en zinvol maakt. De dienende rol van cognities toont zich in de liefde op diverse manieren. Ten eerste is er het gemak waarmee de liefhebbende persoon de aantrekkelijke kanten van de geliefde persoon ziet en de onaantrekkelijke kanten negeert. Vervolgens is er een eenzijdig en partijdig scherp bewustzijn van het doen en laten van de geliefde persoon, alsof het universum een belichtingstechnicus in dienst genomen heeft die de geliefde heel de dag in de spotlights zet waardoor de rest van de wereld een beetje grauwer en onbeduidender lijkt. En ten slotte is er buitensporig veel aandacht voor zaken die de geliefde waardeert, zaken die een rol in zijn of haar leven spelen, en die de liefhebbende persoon wil leren kennen op een manier en met een intensiteit die geen weerspiegeling is van de intrinsieke betekenis van deze zaken voor de liefhebbende persoon.

De cognitieve vermogens van de liefhebbende persoon worden in de liefde ingezet in een project dat draait om identificatie en het in stand houden van een meervoudig subject. ${ }^{8}$ Deze dienende rol van cognitie, kenmerkend voor de liefhebbende blik, treedt met name pregnant op de 
voorgrond tijdens de verliefdheid, als er nog geen sprake is van een meervoudig subject, maar wel van identificatie en van een sterk verlangen naar het vormen van een band en het constitueteren van een meervoudig subject. De verliefde persoon wil het woordje 'wij' kunnen gebruiken alsof het vanzelfsprekend naar hem en zijn geliefde verwijst, naar een stel uit één stuk, Het Stel, die twee waarom het draait in de romantic comedy die zijn leven is. De biologen hebben er een verklaring voor: testosteron en dopamine, hormonen die voor eenzijdige aandacht en positieve illusies zorgen. Alsof onze geliefde de mooiste mens van de wereld is. Het schijnt een list van de evolutie te zijn. ${ }^{9}$ Omwille van de voortplanting is de liefde blind. De waarheid doet er niet toe, althans niet de neutrale, objectieve waarheid. Er moet gecopuleerd worden! En waar is wat werkt.

Maar het loont de moeite met iets meer aandacht te kijken naar de verhouding tussen cognitie en evaluatie die door liefde wordt afdwongen. Liefde maakt namelijk niet alleen blind, maar ook helderziend. ${ }^{10}$ Als we het evolutionaire verhaal serieus willen nemen, dan gaat het bij mensen in de voortplanting namelijk helemaal niet om die eerste spannende nacht. Die opent alleen de deur voor een band die zowat twintig jaar zal omspannen, een periode waarin het op toewijding aankomt en op zorg, omdat het van menselijke ouders vele jaren van inspanning, overgave en samenwerking vraagt voordat het nageslacht zelf weer voor nageslacht zal kunnen zorgen. Het feit dat cognitie in de liefde dienstbaar is aan de positieve evaluatie van de geliefde persoon doet dus ook iets anders. Het brengt een tweede gemeenplaats in stelling, een tegeltjeswijsheid die laat zien dat cognitie in het relationele domein ook een kwestie is van engagement en overgave: zoekt en gij zult vinden. Anders gezegd: het zoeken naar de goede kwaliteiten van de geliefde persoon zal beloond worden doordat deze goede kwaliteiten vanwege en in reactie op de zoektocht van de liefhebbende persoon ook inderdaad zullen blijken te bestaan. Dit is geen vreemde magie: als iemand verliefd op jou is, idealiseert hij niet alleen jou, maar ook zichzelf. Hij zal zich van zijn beste kant laten zien, zal een en al hoffelijkheid, attentheid en zorgzaamheid betrachten, en dat zijn nu precies de eigenschappen die in jou hun evenbeeld zullen oproepen. De liefde maakt daarmee zichzelf waar. Jij zult om van te houden zijn omdat hij van je houdt, zoals hij om van te houden is omdat jij van hem houdt. 


\section{$6 \quad$ Aandachtig, welwillend, partijdig. En betrokken}

De vraag die op dit punt in ons argument gesteld moet worden is of de roze bril van de liefhebbende persoon kwalijker is in een therapie dan de blindheid van de wetenschapper voor zijn eigen perspectief. Gegeven dat de functie van cognitieve vaardigheden vooral gelegen is in het kunnen scheiden van schijn en wezen, in het kunnen ontmaskeren van ambigue gegevenheden, hangt het antwoord op deze vraag af van de aard van de ambiguïteit waarvan in een therapie sprake is. Dat kan verhelderd worden aan de hand van de volgende vier scenario's:

Moedervlek. Ingrid maakt zich zorgen om een onrustige moedervlek op haar schouder. De huisarts verwijdert de moedervlek en stuurt het stukje huid naar het laboratorium om te laten onderzoeken of het soms om huidkanker gaat.

Pleister. Henk snijdt zich per ongeluk in zijn rechterhand bij het pakken van een gebroken glas. Ingrid helpt hem met het aanbrengen van een pleister op de wond.

Bloemetje. Henk komt thuis met een mooi bosje bloemen voor Ingrid. Hij probeert zo weer een beetje goed te maken dat hij zijn vrouw gisteren aan tafel uitgescholden heeft.

Fruitmand. Anne wordt na haar tweede acute alcoholvergiftiging ter observatie een dagje langer in het ziekenhuis gehouden. Op het nachtkastje staat een fruitmand die ze van haar opa en oma heeft gekregen.

In Moedervlek is er sprake van een ambiguïteit die inderdaad om specialistische cognitieve vaardigheden vraagt. Ingrid weet niet wat zij van die moedervlek moet denken en de huisarts weet dat ook niet. Een deskundig onderzoek in een laboratorium moet uitsluitsel geven. Van zo'n ambiguïteit is in Pleister helemaal geen sprake. Henks hulpvraag is volstrekt duidelijk. Er is vrijwel geen cognitieve inspanning nodig om dat te begrijpen. Pleister is wat dat betreft op betrekkingsniveau even ongecompliceerd als Moedervlek: in Pleister is er simpel behoefte aan alledaagse zorg zoals er in Moedervlek even simpel behoefte is aan specialistische kennis.

In Bloemetje is er daarentegen sprake van complicaties op betrekkingsniveau. Misschien is er geen sprake van ambiguitteit en ook geen sprake, of geen sprake meer, van meningsverschillen, van oppositie, van vijandig onbegrip. Waarschijnlijk is het volkomen duidelijk: Henk heeft gescholden en daar heeft hij spijt van. En nu hoopt hij dat Ingrid genoegen neemt met zijn bosje bloemen zodat zijn wangedrag vergeven en vergeten kan worden en er geen pijn, verdriet of onbegrip meer op de bodem van hun ziel achterblijft. Henks gebaar is een uiting van zorg, van goede wil, en hij hoopt 
daarmee een succesvol beroep te doen op Ingrids goede wil, en op haar zorg voor hun relatie, zodat zij weer samen met een schone lei verder kunnen. Of Henks interventie - om er zo'n groot woord aan te besteden voldoende is en of er daarmee voldoende transparantie is ontstaan over onderliggende ambiguïteiten, zodanig dat er geen behoefte meer is aan een cognitieve inspanning van Henk en Ingrid samen, is op basis van dit schetsmatige scenario natuurlijk niet vast te stellen. Maar eventueel verborgen blijvende ambiguïteiten vragen vooral om een cognitieve inspanning van betrokken geliefden, die in gezamenlijkheid hun best doen te zoeken naar aanknopingspunten voor elkaars hoffelijkheid, attentheid en zorgzaamheid. Er is in Bloemetje geen plaats voor een zogenaamde objectieve weging van het gemak van Henks gebaar, de ernst van zijn grievende vloeken, of de omvang van Ingrids offer voor de lieve vrede. Natuurlijk zou een goede vriend kunnen helpen om het onbegrip verder op te klaren. Om de ernst van het conflict te wegen is er echter geen perspectiefloos perspectief nodig maar een cognitieve inspanning die ten dienste staat van de oprechte, evenwichtige en liefdevolle betrokkenheid van beiden bij het gezond voortbestaan van hun relatie.

En hoe zit dat dan in Fruitmand? Misschien is op het eerste gezicht niet duidelijk of er sprake is van complicaties op betrekkingsniveau. Anne ligt in het ziekenhuis en opa en oma hebben hun bezorgdheid en liefde getoond door een fruitmand te laten bezorgen. Net als Henk in Bloemetje. Duidelijk. En aardig. Toch is het scenario evident beladen en gecompliceerd. Aan alle kanten duiken ambiguïteiten op. Weten opa en oma dat het Annes eigen schuld is dat zij in het ziekenhuis ligt? Is het haar eigen schuld? Proberen opa en oma verborgen te houden dat zij weten dat het Annes eigen schuld is? Kiezen opa en oma partij voor Anne of is de fruitmand juist bedoeld om te onderstrepen dat Anne ziek is en dat zij daardoor een grote last voor Henk en Ingrid is? En ga zo maar door.

De betrokkenen weten in dit scenario niet hoe de anderen de situatie interpreteren en evalueren. En wellicht weten ze niet eens hoe zijzelf het scenario interpreteren en evalueren. De handelingen die in dit scenario verricht worden delen zelf wezenlijk in deze ambiguïteit. Dat is het mooie, bijzondere, maar soms ook frustrerende aan sociale handelingen, handelingen die principieel door een groep mensen worden verricht. Daarbij gaat het niet om een groep mensen die formeel als één collectief opereert, maar om handelingen van individuen die gericht zijn op anderen en die daardoor voor hun betekenis wezenlijk afhankelijk zijn van hoe die anderen de handeling interpreteren en concipiëren. Opa en oma hebben 
Anne een fruitmand laten bezorgen. Maar wat hebben ze daarmee gedaan?

Etnomethodologen als Garfinkel en Goffman hebben al in de zeventiger jaren van de vorige eeuw duidelijk gemaakt dat er geen objectieve, onbevooroordeelde en transparante kennis van dit soort handelingen mogelijk is. ${ }^{11}$ Ook als de intentie van opa en oma voor henzelf volkomen eenduidig en transparant is, dan nog zijn zij overgeleverd aan Annes vermogen - of onvermogen - in hun handeling alleen en precies die intentie te zien. En juist omdat deze afhankelijkheid aan de kant van opa en oma een intrinsiek aspect van het scenario is, is het niet eens mogelijk dat de intentie van opa en oma voor henzelf volkomen eenduidig en transparant is. Tenzij zij met het sturen van die fruitmand helemaal geen betrekking met Anne proberen aan te gaan. Maar daarmee zouden zij hun handeling een selfdefeating intentie meegeven.

In Fruitmand zijn de ambiguïteiten een functie van onheldere, niet goed afgestemde en onvoldoende gedeelde interpretaties. Die ambiguïteiten kunnen in het scenario niet geëlimineerd worden door het innemen van een onbetrokken, afstandelijk perspectief. Dat is zelfs zo als er specifieke, onderliggende beperkingen bij de betrokkenen zijn waardoor het onbegrip gevoed en versterkt wordt. Ook als er van interpretatieve beperkingen sprake is, vragen de ambiguïteiten in Fruitmand om het in gezamenlijkheid verkennen van elkaars begrip, om de creatie van een meervoudig subject, om een cognitieve inspanning die dienstbaar is aan het realiseren van een gezond 'wij'.

Met deze korte bespreking van bovenstaande scenario's willen wij het volgende punt maken. Alleen in scenario's die op Moedervlek lijken is het geboden te investeren in wetenschappelijke kennis, kennis die gebaat is bij en gebaseerd is op een zo perspectiefloos mogelijk perspectief. Wij voegen hier een empirische hypothese aan toe: het leeuwendeel van scenario's waarin sprake is van psychisch lijden lijkt niet op Moedervlek maar eerder op Fruitmand. ${ }^{12}$

Wij ontkennen niet dat er psychopathologische situaties bestaan die meer op Moedervlek lijken dan op Fruitmand. De kennis die de therapeut van zijn cliënten nodig heeft om een betrekking met ze aan te kunnen gaan en te onderhouden, zal kennis kunnen zijn, en in betreffende gevallen ook kennis moeten zijn, van pathologieën die bestaan op een onderliggend niveau. Als de hardware kapot is heb je immers niets aan je software, hoe geavanceerd je besturingssysteem ook is. Maar pas op: deze beeldspraak is notoir problematisch. We hebben in de wereld van de biopsychosociale fenomenen vaak geen flauw idee welke niveaus we helder en eenduidig 
kunnen onderscheiden noch hoe wij die eenmaal onderscheiden niveaus dan hiërarchisch zouden kunnen ordenen. ${ }^{13}$ Juist die plasticiteit en het bijbehorende non-reductionisme versterken ons vermoeden dat het aantal psychopathologische problemen dat op Fruitmand lijkt veel en veel groter is dan het aantal problemen dat op Moedervlek lijkt. En zelfs in die gevallen waarin het - uiteindelijk - om een versie van Moedervlek blijkt te gaan, zal er gedurende lange tijd, zowel in de aanloop als in de afwikkeling, sprake zijn van mensen die het moeilijk hebben om onbekommerd te blijven deelnemen aan een liefdevolle betrekking. Dat zal des te meer zo zijn als het om een serieus probleem in de hardware gaat, zoals bijvoorbeeld in het geval van een ernstig autisme, een diep verstandelijke beperking of een zware vorm van schizofrenie. Dan hebben we het immers over een chronische aandoening en niet over een weg te snijden tumor zoals in Moedervlek. Juist dan zal de behandeling neerkomen op het leren leven met de aandoening en dat zal toch echt een kwestie zijn van het organiseren van een liefdevolle betrekking waarin er recht gedaan kan worden aan de psychopathologie.

In scenario's als Fruitmand, net als in scenario's als Pleister en Bloemetje, is er geen behoefte, althans niet primair, aan een investering in wetenschappelijke kennis. Er kan in dergelijke scenario's serieus en indringend behoefte zijn aan cognitieve inspanningen omdat er sprake kan zijn van ernstige ambiguïteiten. De cognitieve inspanningen waaraan in dergelijke scenario's dan behoefte is, zijn echter inspanningen die cruciaal dienstbaar zijn aan een onderliggende en omvattende positieve evaluatie, aan het steunen en versterken van het vermogen van alle betrokkenen om oprecht, evenwichtig en liefdevol te zoeken naar en bij te dragen aan het gezonde voortbestaan van de relatie waarvan tussen deze betrokkenen sprake is. Het is wat ons betreft de taak van de therapeut om op de juiste wijze deel te nemen aan deze liefdevolle zoektocht.

\section{$7 \quad$ Liefdevolle betrekking}

Wat doet een therapeut die een betrekking met zijn cliënten aangaat? Wat kan hij als professional nog betekenen op het moment dat Henk, Ingrid en Anne elkaar niet meer kunnen bereiken en ieder tracht hem van haar of zijn gelijk te overtuigen? Op zo'n moment kan hij zich niet meer verbergen achter zijn wetenschappelijke kennis en zal hij een betekenisvolle relatie met hen moeten aangaan. Om wat voor betrekking gaat het in een therapie? 
Drie voorwaarden lijken ons cruciaal. Op de eerste plaats zal de therapeut moeten beseffen dat hij in de therapie als gastheer ${ }^{14}$ zal moeten functioneren. Dat brengt specifieke paternalistische verantwoordelijkheden met zich mee. De therapeut zal het voortouw moeten nemen en de kaders moeten bieden. De therapeut heeft namelijk altijd, qualitate qua, te maken met cliënten die doordrongen zijn van hun eigen onvermogen of dat van hun partners, cliënten die te lang hebben doorgesukkeld, tot het echt niet anders meer ging, en die nu angstig, schuldbewust, hulpeloos en defensief de therapie binnen schuifelen. Henk natuurlijk heel anders dan Anne en Ingrid, maar ieder zal op eigen wijze beseffen dat zij als gezin gefaald hebben, dat zij het niet zelf hebben kunnen oplossen en dat zij nu niet anders kunnen dan hun lot in de handen van de therapeut te leggen. Daarbij ligt het tevens volstrekt voor de hand dat zij alle drie zullen menen dat de last van de schuld tussen hen drieën niet gelijk verdeeld is. Alle drie zullen zij erbij gebaat zijn de last van de schuld voor hun onmacht ergens anders te leggen, of het nu is in de onwil of het onvermogen van de anderen, of in het noodlot van gegevenheden waaraan zij overgeleverd zijn. De therapeut zal er daarom voor moeten waken geen partijdige verdenkingen op zich te laden. Hij zal zich niet moeten laten verleiden tot het bevestigen van scheve gezichten. Hij lijkt wat dat betreft wel wat op een ouder die van al zijn kinderen evenveel wil houden. De therapeut zal moeten beseffen dat zijn cliënten niet in staat zullen zijn tot een gelijkwaardige rol in de betrekking en van zijn cliënten aanvankelijk niet veel meer kunnen verwachten dan een kinderlijke, naïeve, afhankelijke, en grenzeloze overgave. Zij zullen geneigd zijn zijn deskundigheid en almacht te overschatten, zoals kinderen graag denken dat hun vader alles kan. De therapeut zal daarom moeten onderzoeken hoe hij daarop in zal kunnen spelen, hoe hij deze kinderlijke afhankelijkheid en zijn eigen uitvergrote autoriteit in zal kunnen zetten om bij zijn cliënten de ontwikkeling te stimuleren die hij op het oog heeft: dat zij op een meer volwassen manier hun rol zullen leren spelen in hun betrekking. Hij zal daarbij onvoorwaardelijk vertrouwen moeten tonen: natuurlijk gaat het met hen goed komen!

De therapie zal daarom, op de tweede plaats, een flinke cognitieve inspanning van de therapeut vragen. Hij zal moeten achterhalen wat de mogelijkheden en onmogelijkheden van zijn cliënten zijn. Dat is in ons voorstel geen kwestie van diagnostiek. Tenminste, geen geformaliseerde, methodische diagnostiek. Vergelijk dit maar met hoe nieuwe ouders hun jonggeborene willen leren kennen: met een ongekend gretige en liefdevolle aandacht! De therapeut zal wat dat betreft, net als een ouder, niet primair geïnteresseerd zijn in een neutraal en onbetrokken verslag van de zoge- 
naamde objectieve eigenschappen van zijn cliënten, maar zal het liefst een zo gunstig mogelijk zicht krijgen op die eigenschappen waarmee hij het meeste kan, waarmee hij een klik heeft, zodat hij zijn cliënten ook voor hém kan interesseren. Dat wil de therapeut, om zo een gunstige dynamiek op gang te kunnen brengen. Hier toont zich de dienende rol die cognitie in een therapeutische betrekking heeft. De therapie is een zoektocht naar een 'wij' dat het bloeiende middelpunt van de wereld kan zijn. Dit betekent natuurlijk niet dat de therapeut zichzelf voor de gek moet proberen te houden, maar wel dat hij zijn cognitieve inspanningen ten dienste stelt van een professioneel optimisme: dat het hem met deze mensen gaat lukken!

Dat betekent, op de derde plaats, dat de therapeut zich zal moeten realiseren dat hij het in de therapie niet alleen kan. De therapie is een gezamenlijke constructie van een nieuw meervoudig subject, een 'wij'. Zowel de therapeut als zijn cliënten zijn daarin actief. Zij zullen elkaar aftasten, zullen proberen zicht te krijgen op elkaars wederzijdse verwachtingen en zullen de ruimte verkennen die er binnen de therapie is voor hun eigen emotionele, sociale, intellectuele en communicatieve beperkingen, eigenaardigheden en onhebbelijkheden. Natuurlijk doen ze dat niet systematisch en formeel. Maar bovenal: ze doen dat niet eenzijdig. Ze doen het interactief, relationeel, met inachtneming van hun eigen gebrekkigheden, hun eigen gebruiksaanwijzing. Zowel de therapeut als zijn cliënten zijn daarbij geëngageerde deelnemers die hun situatie definiëren, impliciet dan wel expliciet, bewust dan wel onbewust. Daarbij zullen zij elkaar niet als geïsoleerd functionerende buitenstaanders kunnen beschouwen, en ook niet als passieve, kneedbare bouwstenen. De therapie zal duidelijk moeten maken dat de cliënten geen klanten zijn die zorg komen kopen. Daarvoor ontbreekt het hen immers aan de regie die van de klant koning maakt. Ook zijn de cliënten geen hulpeloze leken die zich komen overleveren aan een deskundige die als het ware buiten hen om de strijd met de demonen aan zal gaan en zal winnen. Cliënten kunnen hun leven immers niet uitbesteden aan hun therapeut. Cliënten lijken wat dat betreft meer op de kinderen in een gezin die enthousiast of met tegenzin zullen moeten leren hoe zij hun eigen leven in de hand zullen kunnen krijgen.

Onze stelling daarbij is dat de therapie voltooid zal zijn zodra de cliënten in staat zijn op een volwassen, gelijkwaardige wijze deel te nemen aan hun betrekking met de therapeut. Dat zal immers het moment zijn waarop de cliënten hun therapeut niet meer nodig hebben, waarop zij zullen beseffen dat het in het leven niet draait om het in stand houden van een therapeutische betrekking, maar wel om het in stand houden van een 
liefdevolle betrekking met hen die hen dierbaar zijn. Zo'n liefdevolle betrekking zullen ze dan ervaren hebben in de therapie, die in feite een beschermde, pedagogische setting is waarin kwetsbare mensen kunnen oefenen in het aangaan van een liefdevolle betrekking - met een therapeut, met elkaar, en met zichzelf.

Dit betekent natuurlijk niet dat Henk, Ingrid en Anne pas afscheid van de therapie zullen kunnen nemen als Anne volwassen is. Een volwassen gezin is iets anders dan een verband tussen volwassenen. In een volwassen gezin speelt ieder gezinslid zijn eigen rol, op volwaardige wijze, en dat betekent voor Anne dat ze de rol moet leren spelen van een beminnelijke zeventienjarige dochter die van haar ouders houdt op een manier die past bij zeventienjarige dochters. Dat is nog lang geen volwassen rol en dat moeten Henk en Ingrid ook helemaal niet willen. Zij hebben een dochter van zeventien, van wie ze houden, zoals ze is: een dochter van zeventien!

De therapeut zal ze daar moeten brengen, gedreven door een niet objectief gefundeerde positieve evaluatie van zijn cliënten, getuigend van een natuurlijke zelfverzekerdheid, onvoorwaardelijk en volstrekt onbaatzuchtig in de ban van deze mensen. Verbeelden wij ons dit, of lijkt deze korte schets van de attitude van de therapeut op de naturalistische, vormende, dynamische, onvoorwaardelijke en onbaatzuchtige ouderliefde waarover wij in paragraaf 1 spraken ${ }^{15}$

\section{Het hoge woord is er uit: nous voulons de l'amour!}

De moderne verzorgingsstaat lijkt op het verkeerde paard gewed te hebben. Wij investeren massaal in kennis, in wetenschappelijk verantwoorde, zogenaamd perspectiefloze kennis. Wij zijn ons daarbij niet bewust van de blindheid die we daarmee over de geestelijke gezondheidszorg afroepen. De nadruk op de groei van kennis bedreigt de ontwikkeling van onze relationele vaardigheden. Daardoor verkijken wij ons op het therapeutische belang van de liefhebbende blik, de betrokken aandacht voor wat beminnelijk is in mensen die psychisch lijden.

Het is tijd voor een radicale omwenteling, met name in de opleiding van psychotherapeuten. Juist daar staan de klinische vaardigheden immers steeds meer in dienst van richtlijnen die door wetenschappelijke bevindingen gedicteerd worden. Juist daar groeit de blindheid voor de aantrekkingskracht van perspectiefloze kennis, een buitengewoon ironische blindheid. 
Het is de hoogste tijd voor het ontwikkelen van onze liefde. De liefde die meer ziet.

\section{Bibliografie}

Bransen, J. (2010) Word zelffilosoof. Diemen: Veen Magazines.

Bransen, J. (2011) Nou, zeg, waar bemoei je je mee, Algemeen Nederlands Tijdschrift voor Wijsbegeerte 103(1), pp. 4-20.

Bransen, J. (2014) Loving a Stranger, in: Maurer, C., T. Milligan en K. Pacovska (red.) Love and Its Objects: What Can We Care For? Basingstoke: Palgrave Macmillan, pp. 143-159.

Bell, D. (2010) The Dynamics of Connection: How Evolution and Biology Create Caregiving and Attachment, Plymouth: Lexington Books.

Fisher, H., A. Aron en L. Brown (2006) Romantic Love: A Mammalian Brain System for Mate Choice, Philosophical Transactions of the Royal Society, B, Biological Sciences $36 \mathbf{1}(1476)$, pp. 2173-2186.

Frank, J.D. en J.B. Frank (1993) Persuasion and Healing: A Comparative Study of Psychotherapy (third edition). Baltimore, MD/London: Johns Hopkins University Press.

Garfinkel, H. (1967) Studies in Ethnomethodology. New York: Prentice Hall

Gilbert, M. (1990) Walking Together: A Paradigmatic Social Phenomenon, Midwest Studies in Philosophy 15, pp. 1-14.

Godfrey-Smith, P. (2003) Theory and Reality: An Introduction to the Philosophy of Science. Chicago: Univeristy of Chicago Press.

Goffman, E. (1959) The Presentation of Self in Everyday Life. New York: Doubleday.

Hacking, I. (1999) The Social Construction of What? Cambridge, MA: Harvard University Press.

House, R. en D. Loewenthal (red.) (2008) Against and For CBT. Towards a constructive diagologue? Ross-on-Wye: PCCS Books.

Kahneman, D. (2011) Ons feilbare denken. Amsterdam/Antwerpen: Uitgeverij Business Contact.

Leezenberg, M. en G. de Vries (2001) Wetenschapsfilosofie voor geesteswetenschappen. Amsterdam: Amsterdam University Press.

Murray, S.L., J.G. Holmes en D.W. Griffin (1996) The Self-Fulfilling Nature of Positive Illusions in Romantic Relationships: Love Is Not Blind, but Prescient. Journal of Personality and Social Psychology 71, 1155-1180.

Pope, S. (1992) Agape and Human Nature: Contributions From Neo-Darwinism, Social Science Information 31, pp. 509-529.

Sterelny, K. (2003) Thought in a Hostile World: The Evolution of Human Cognition. Oxford: Blackwell.

Walter, S. en M. Eronen (2011) Reduction, Multiple Realizability and Levels of Reality, in: French, S. en J. Saatsi, The Continuum Companion to the Philosophy of Science. London: Continuum, pp. $138-156$.

Williams, B. (2002) Truth and Truthfulness: An Essay in Genealogy, Princeton: Princeton University Press. 


\section{Over de auteurs}

Jan Bransen is hoogleraar Filosofie van de gedragswetenschappen aan de Radboud Universiteit te Nijmegen. Hij studeerde filosofie en sociologie te Utrecht waar hij in 1989 promoveerde op een proefschrift over post-Kantiaans scepticisme. Hij heeft internationaal uitgebreid gepubliceerd op het terrein van persoonlijke identiteit, autonomie, en praktisch redeneren. Momenteel schrijft hij vooral in het Nederlands voor een breder publiek. Hij doet onderzoek naar de rol die liefde speelt in het menselijk vermogen zich op het eigen gedrag en denken te betrekken. Enkele recente publicaties daaromtrent zijn 'Loving a Stranger', in Maurer et.al., Love and Its Objects: What Can We Care For?, Palgrave 2014, en 'Self-Knowledge and Self-Love', Ethical Theory and Moral Practice 2015. Met Giel Hutschemaekers schreef hij ook 'The rise of CBT and its consequences for the psychotherapist' dat momenteel under review is.

Giel Hutschemaekers is hoogleraar Geestelijke Gezondheidszorg aan de Faculteit der Sociale Wetenschappen van de Radboud Universiteit te Nijmegen. Tevens is hij als hulpverlener en onderzoeker werkzaam bij Pro Persona, een grote regionale GGZ instelling in Zuid West Gelderland. Hij studeerde filosofie te Straatsburg (Frankrijk), theologie te Brugge (België) en (klinische) psychologie te Tilburg. Na zijn studie was hij verbonden aan de sectie cultuurpsychologie van de Universiteit van Tilburg, alwaar hij in 1990 promoveerde op een onderzoek naar culturele determinanten van aard en omvang van psychische problemen in Nederland. Vervolgens was hij werkzaam bij het Trimbos-instituut, waar hij zich toelegde op onderzoek naar kwaliteit van zorg en professionaliseringsvraagstukken. Sinds 2000 combineert hij de functie van hoogleraar aan de RU met werkzaamheden in de zorgpraktijk binnen Pro Persona. Hij is op dit moment betrokken bij de inrichting van de basiszorg GGZ en verricht onderzoek naar effecten van stepped care, het onderscheid tussen generalistische en specialistische GGZ en de rol van therapeut en cliënt daarbij.

\section{Noten}

1. Zie Sterelny (2003).

2. Zie Pope (1992) en Bell (2010).

3. Zie bijvoorbeeld Kahneman (2011).

4. Zie House en Loewenthal (2008).

5. Zie de eerste helft van iedere standaardinleiding in de wetenschapsfilosofie, bijvoorbeeld Godfrey-Smith (2003) of Leezenberg en De Vries (2001). 
6. Zie bijvoorbeeld Garfinkel (1967) en Goffman (1959).

7. Laat duidelijk zijn dat wij hier geen simpel sociaal constructivisme vooronderstellen, maar wel recht willen doen aan twee fascinerende processen die kenmerkend zijn voor de verhouding tussen wetenschappelijke kennis en sociale werkelijkheid, processen die jarenlang door Ian Hacking onderzocht zijn: 'making up people' en 'the looping effect of human kinds'. Zie bijvoorbeeld Hacking (1999).

8. Zie Gilbert (1990). Zie hierover ook Bransen (2010).

9. Zie Fisher, Aron en Brown (2006).

10. Murray, Holmes en Griffin (1996).

11. Zie voetnoot 6 .

12. Wij accepteren dat dit een empirische hypothese is die niet slechts met argumentatieve middelen onderbouwd kan worden. Toch denken wij dat de bewijslast bij onze tegenstanders hoort te liggen. Ons belangrijkste argument daarvoor is dat de bewering dat de meeste psychopathologische scenario's op Moedervlek lijken, een bewering is, dat wil zeggen een interpretatieve, sociale handeling, die niet met zuiver empirische evidentie onderbouwd kan worden maar een zoektocht impliceert die om rationele waarachtigheid draait. Zie Williams (2002).

13. Zie bijvoorbeeld Walter en Eronen (2011).

14. Zie Bransen (2011).

15. Zie Bransen (2014). 